\title{
Electro-gene therapy in a human oral tongue cancer cell by intratumoral injection of pcDNA3.1-p27 ${ }^{\mathrm{Kip} 1} \mathrm{wt}$
}

\author{
Supriatno \\ Department of Oral Medicine \\ Faculty of Dentistry, Gadjah Mada University \\ Yogyakarta - Indonesia
}

\begin{abstract}
Oral tongue cancers are characterized by a high degree of local invasion and a high rate of metastases to the cervical lymph nodes. Also, treatment options for this cancer are limited. However, a new strategy for refractory cancer, gene therapy is watched with keen interest. Recently, a novel method for high-efficiency and region-controlled in vivo gene transfer was developed by combining in vivo electro-gene therapy and intratumoral plasmid DNA injection. In the present study, a nonviral gene transfer system, in vivo electrogene therapy in human oral tongue cancer cell, SP-C1 xenograft was examined. The aim of the study is to examine the efficiency of transfection of exogenous $p 27^{\text {Kip } 1}$ gene by electroporation and the antitumor activity of $p 27^{\text {Kip } 1}$ gene therapy in human oral tongue cancer xenografts using pcDNA3.1-p27 Kipl wild type (wt) and pcDNA3.1 empty vector with the local application of electric pulses. To evaluate this in vivo gene transfer method, the enhanced green fluorescence protein (EGFP) gene was transfected into xenografts by electroporation. The efficiency of transfection of exogenous $p 27^{\text {Kip } 1}$ gene by electroporation was confirmed by Western blotting analysis. To estimate the reduction of oral tongue cancer xenografts by this method, the size of SP-C1 xenografts in nude mice after electroporation with wild type $p 27^{\text {Kip } 1}$ gene was measured. The growth of tumors was markedly suppressed by wild type $p 27^{\text {Kip } 1}$ gene transfection by electroporation compared with transfection of empty vector only. Moreover, histological specimens revealed apoptotic cell death was increased in wild type $p 27^{K i p 1}$-transfected tumors than empty vector. These results suggest that it is possible to transfer wild type $p 27^{\text {Kipl }}$ into human oral tongue cancer xenografts using electroporation. Wild type $p 27^{\text {Kipl }}$ has a high-potencially to suppress the growth of tumors. Finally, combination system of pcDNA3.1-p2 $7^{\text {Kipl } 1}$ wt-injected tumor and electroporation might be used for human oral cancer.
\end{abstract}

Key words: Intratumoral, Wild type p $27^{\text {Kipl }}$, Human oral tongue cancer, Electroporation

Correspondence: Supriatno, c/o: Bagian Penyakit Mulut, Fakultas Kedokteran Gigi Universitas Gadjah Mada. Jl. Denta 1, Sekip Utara, Yogyakarta 55281, Indonesia. E-mail: pridentagama@lycos.com, Phone/Fax: 0274-515307.

\section{INTRODUCTION}

Oral tongue cancers are characterized by a high degree of local invasion and a high rate of metastases to the cervical lymph nodes. Moreover, oral tongue cancer frequently shows local recurrence after initial treatment, probably due to microinvasion and/or micrometastasis of tumor cells at the primary site. ${ }^{1}$ Despite advanced in surgery, radiotherapy and chemotherapy, the survival of patients with oral tongue cancer has not significantly improved over the past several decades. Also, treatment options for recurrent or refractory oral cancers are limited. ${ }^{2}$ Furthermore, the ratio of mortality or incidence in 1980 and 1990 was 0.48 and 0.47 , respectively, ${ }^{3}$ and the prognosis has not changed during the past 10 years. However, as a new strategy for refractory cancer, gene therapy is watched with keen interest.

Electro-gene therapy or electroporation has been developed for the purpose of achieving highly efficient in vitro gene or drug transfer. ${ }^{4,5}$ This system provides markedly higher efficiency transfer compared with other nonviral transfer system, including cationic liposomes. ${ }^{6}$ Electroporation has been applied to in vivo drug transfer for cancer treatment and clinical trial has been started. ${ }^{7}$
Electroporation has become more and more popular as an effective technique for introduction of foreign DNA into cells of various kinds of mammalian cells, ${ }^{8,9}$ for investigation of gene regulation, ${ }^{10}$ and has been demonstrated to be highly useful in transfecting human hematopoetic stem cells for gene therapy. ${ }^{11}$ However, the transfection efficiency in mammalian cells using in vivo electroporation has received little attention ${ }^{12}$ and usually is still low, typically about $0.01-1 \% .{ }^{13}$ Because electroporation is a physical method, it has a little biological side effect and is free of chemical toxicity. ${ }^{10}$

Many types of methods and techniques for in vivo gene transfer have been developed, and some of them have already been applied in clinical trials. ${ }^{4}$ Nonviral gene transfer, "naked" plasmid DNA is an ideal system for gene transfer. A plasmid mediated method would be economical and easy because use of this system obviates the necessity to construct viral vectors, establish clones of producer cells, assess viral titers and presence of replication-competent helper virus, which has been known to activate passive oncogenes. The transfer procedure could be easily repeated because "naked" plasmid DNA has little antigenicity to the host body. ${ }^{14}$ 
$\mathrm{p} 27^{\mathrm{Kip} 1}$ is an universal cyclin-dependent kinase inhibitor that directly inhibits the enzymatic activity of cyclin-CDK complexes, resulting in cell cycle arrest at $\mathrm{G}_{1}{ }^{15} \mathrm{p} 27^{\mathrm{Kip} 1}$ has an important prognostic factor in various malignancies. Recently, decreased expression of $\mathrm{p} 27^{\mathrm{Kip} 1}$ has been frequently detected in human cancer. ${ }^{16-18}$ In addition, loss of $\mathrm{p} 27^{\mathrm{Kip} 1}$ has been associated with disease progression and an unfavorable outcome in several malignancies. ${ }^{19}$ Furthermore, mice lacking the $\mathrm{p} 27^{\mathrm{Kip} 1}$ gene show an increase in body weight, thymic hypertrophy and hyperplasia of pituitary intermediate lobe adrenocorticotropic hormon cells, adrenal glands and gonadal organ. ${ }^{20)}$ Also, malignant human oral cancer cells transfection with $\mathrm{p} 27^{\mathrm{Kip} 1}$ gene leads to inhibition of proliferation, invasion and metastasis. ${ }^{21,22}$

In the present study, the efficiency of transfection of exogenous $\mathrm{p} 27^{\mathrm{Kip} 1}$ gene by electroporation and the antitumor activity of $\mathrm{p} 27^{\mathrm{Kip} 1}$ gene therapy in human oral tongue cancer xenografts using pcDNA3.1-p2 $7^{\mathrm{Kip} 1}$ wild type (wt) and pcDNA3.1 empty vector with the local application of electric pulses was evaluated.

\section{MATERIALS AND METHODS}

\section{Cell and cell culture}

SP-C1 cells were isolated from a cervical lymph-node metastasis of an oral squamous cell carcinoma patient in our laboratory. $^{22}$ The original tumor of SP-C1 cells was moderately differentiated squamous cell carcinoma of tongue, and was not invasive into muscle layer. Cells were maintained in Dulbecco's modified eagle medium (DMEM, Sigma, St Louis, MO, USA) supplemented with $10 \%$ fetal calf serum (FCS, Moregate BioTech, Bulimba, Australia), $100 \mu \mathrm{g} / \mathrm{ml}$ streptomycin, and $100 \mathrm{units} / \mathrm{ml}$ penicillin (Invitrogen Corp., Carlsbad, CA, USA).

\section{Construction of a mammalian expression vector}

The mammalian expression vectors pcDNA3.1$\mathrm{p} 27^{\mathrm{Kip} 1} \mathrm{wt}$ (Invitrogen) containing sense oriented human wild type $\mathrm{p} 27^{\mathrm{Kip} 1}$ cDNA was constructed. Briefly, pcDNA3.1 (+) was digested with Kpn1 (Takara Biomedicals, Kusatsu, Japan) and BamH1 (Takara), and dephosphorylated by calf intestinal alkaline phosphate (Roche Diagnostics, Mannheim, Germany). The human wild type p27 $7^{\text {Kip1 }}$ cDNA fragment (0.69 kb Kpn1 and BamH1 fragment) was obtained as a generous gift from Dr. J Massague (Howard Hughes Medical Institute, Memorial SloanKettering Cancer Center, NY). This fragment containing the human wild type $\mathrm{p} 27^{\mathrm{Kip} 1}$ open reading frame was ligated to the prepared cloning site of pcDNA3.1 (+) by T4 DNA ligase (Takara). The direction of the ligated fragmen was confirmed by sequencing analysis with a spesific primer (p27 ${ }^{\mathrm{Kip} 1}$-SQP: 5'-ATGTCAAACGTGGCGAGTGTC3') for human $27^{\mathrm{Kip} 1} \mathrm{cDNA}$ The DNA sequence was determined by the dideoxy chain termination method, using fluorescene-labeled primers and a Thermo Sequenase Cycle sequencing kit (Amersham Pharmacia Biotech, Sweden). Electrophoresis and scanning were performed with a Shimadzu DSQ-500 DNA sequencer (Shimadzu, Kyoto, Japan).

\section{Tumorigenesis in nude mice and electrotransfection}

The oral tongue cancer cell line, SP-C1 cells were trypsinized, washed with PBS, and suspended in saline solution at $1 \times 10^{6}$ cells in $0.1 \mathrm{ml}$. Cell suspension $(0.1 \mathrm{ml})$ was injected into each male nude mouse with Balb/cA Jcl-nu genetic background (Clea Japan, Inc. Tokyo, Japan) subcutan in the back area. A pair of $1 \mathrm{~cm}$ diameter of disc-shaped electrodes (pinsettes-type electrode 449-10 PRG, Meiwa Shoji, Tokyo, Japan) was used to nip the tumor nodule through the skin. A series of eight electrical pulses with pulse length of $1 \mathrm{msec}$ was delivered with a standard square wave electroporator BTX T820 (BTX, Inc, San Diego, CA). The voltage of $100 \mathrm{~V} / 1.0 \mathrm{~cm}$ diameters of xenografts was used. Then, it delivered an appropriate pulse length and frequency of pulses according to previous report. ${ }^{8,9}$ Immediately after electrical pulsing, $20 \mu \mathrm{g}$ of plasmid cDNA or pcDNA3.1-p2 $7^{\mathrm{Kip} 1}$ wt dissolved in $50 \mu \mathrm{l}$ of Tris EDTA buffer was directly injected into the tumor nodule. This electroporation and injection were performed a total of three times at 3-day intervals. Tumor volume and body weight were measured every 3 days from the time electroporation started until the mice were sacrificed. The tumor volume was determined by measuring length $(\mathrm{L})$ and width $(\mathrm{W})$ diameters of the tumor and calculated as $\mathrm{V}=0.4 \times \mathrm{L} \times \mathrm{W}^{2} .21$

\section{Detection of repoter gene expression in vivo}

For fluorescence microscopy, pEGFP-C3 vector (BD Bioscience Clontech)-injected tumors for $48 \mathrm{~h}$ were sectioned and mounted in PBS for immediate microscopy. To visualize EGFP, a Xenon arch lamp and a FITC filter were used on a Zeiss Axioskop. Images were acquired with a color CCD camera and frame-grabbing equipment at identical magnification, light intensity and amplification for each sample pair of tumors from electroporated or nonelectroporated animals, respectively.

\section{Western blotting analysis}

Cell lysates were prepared from the xenograft tumor tissue. Briefly, samples containing equal amounts of protein $(50 \mu \mathrm{g})$ were electrophoresed on a SDS-polyacrylamide gel and transferred to a nitrocellulose filter (PVDF membrane: BioRad, Hercules, CA, USA). The filters were blocked in TBS containing $5 \%$ nonfat milk powder at $37^{\circ} \mathrm{C}$ for 1 hour and then incubated with a 1:500 dilution of the monoclonal antibody against p27 protein (clone 1B4, monoclonal antibody, Novocastra Laboratories, New Castle, UK) as the primary antibody and an Amersham ECL kit (Amersham Pharmacia Biotech). Anti- $\alpha$ tubulin monoclonal antibody (Zymed laboratories, San Fransisco, CA, USA) was used for normalization of Western blot analysis.

\section{TUNEL method}

Apoptosis was analyzed in situ by the TUNEL technique using ApopTag (Oncor, Inc., Gaithersburg, MD, USA), labeling 3'-OH DNA ends generated by DNA 
fragmentation. Mice tumors were fixed in $4 \%$ formaldehyde in PBS (-). Dewaxed paraffin sections were treated with $20 \mu \mathrm{g} / \mathrm{ml}$ proteinase $\mathrm{K}$ in PBS (-) for 10 minutes to digest protein, then treated with $3 \%$ hydrogen peroxide in PBS for 5 minutes to quench endogenous peroxidase activity and equilibrated. TdT enzyme was applied to the cells or sections were incubated at $37^{\circ} \mathrm{C}$ for $1 \mathrm{~h}$. After each step, the sections were rinsed with PBS.

\section{Statistical analysis}

Statistical analysis was performed with a Stat Work program for Macintosh computers (Cricket Software, Philadelphia, PA, USA). Data were analyzed for statistical significance of 95\% with Two-way Anova and Student's t-test.

\section{RESULTS}

Detection of transgene expression in Xenograft

Expression of reporter gene (EGFP) after plasmid injection and electroporation in tumor tissue was assessed

in fresh tissue sections by light microscopy fluorescence imaging. Very few cells were positive when only naked DNA without consecutive electroporation was injected. The combination with electroporation resulted in consistenly efficient transduction of a higher number of cells with EGFP reporter gene (Figure 1).

In vivo effect of $\mathrm{p}^{27^{\mathrm{Kip} 1}}$ wt transfection by electroporation on tumor growth

The mean relative volume for SP-C1 xenografts treated with an injection of pcDNA3.1-p27 ${ }^{\mathrm{Kip} 1} \mathrm{wt}$ or pcDNA3.1 empty vector was shown in Figure 2A. p2 ${ }^{\text {Kip1 }}$-up-regulated tumors (pcDNA3.1-p27 ${ }^{\mathrm{Kip} 1}$ wt-injected) became much smaller than pcDNA3.1 empty vector-injected tumors $(\mathrm{p}<0.01)$. Interestingly, during the experimental period, no loss of body weight was observed in each treatment group, and that no skin region including a burn also was observed (Figure 2B).

\section{Expression of $\mathbf{2} 27^{\mathrm{Kip} 1}$ protein in xenografts}

To evaluate the efficiency of transfection of $\mathrm{p} 27^{\mathrm{Kip} 1}$ gene, the expression of $\mathrm{p} 27^{\mathrm{Kip} 1}$ protein by Westen bloting

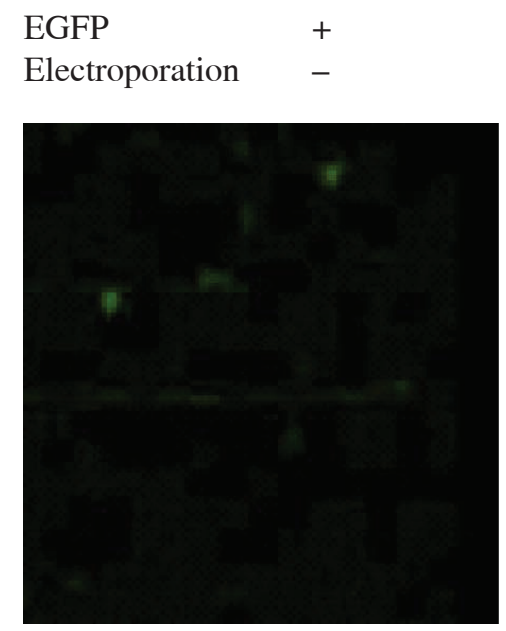

$2.1 \pm 0.3$

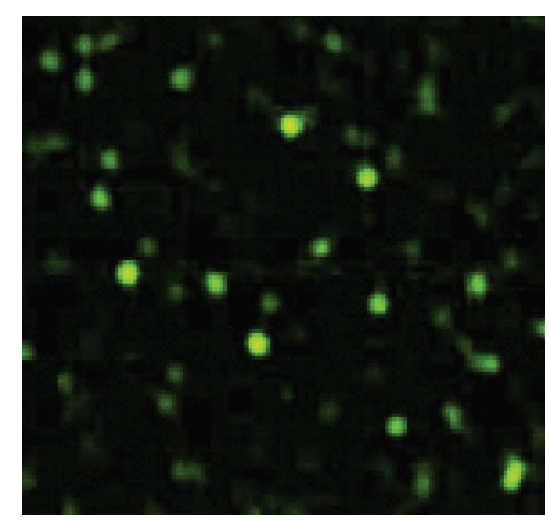

$37.5 \pm 3.5$

Figure 1. Detection of reporter gene expression.

(A)

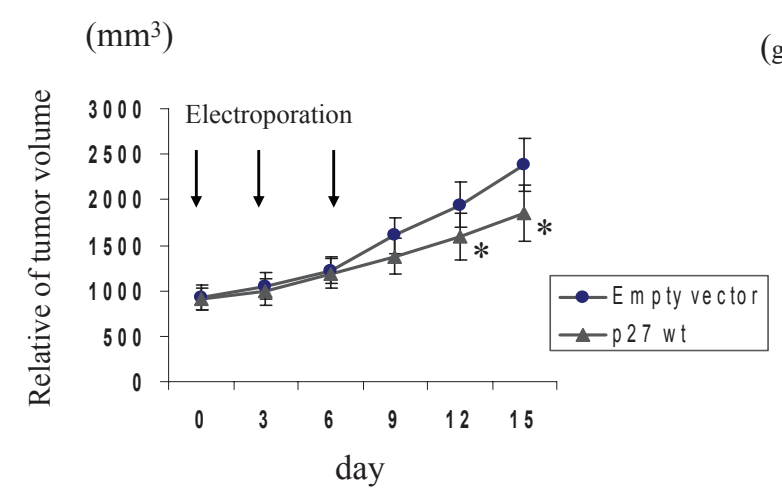

(B)

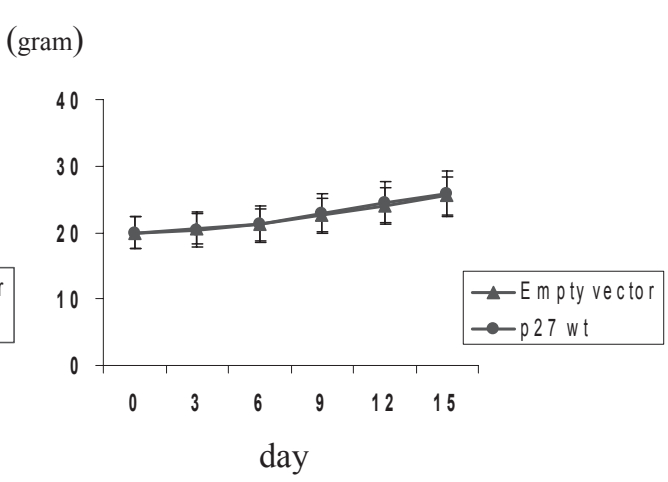

Figure 2. (A) Growth of tumors formed by transfectants, (B) change of body weight in mice. 


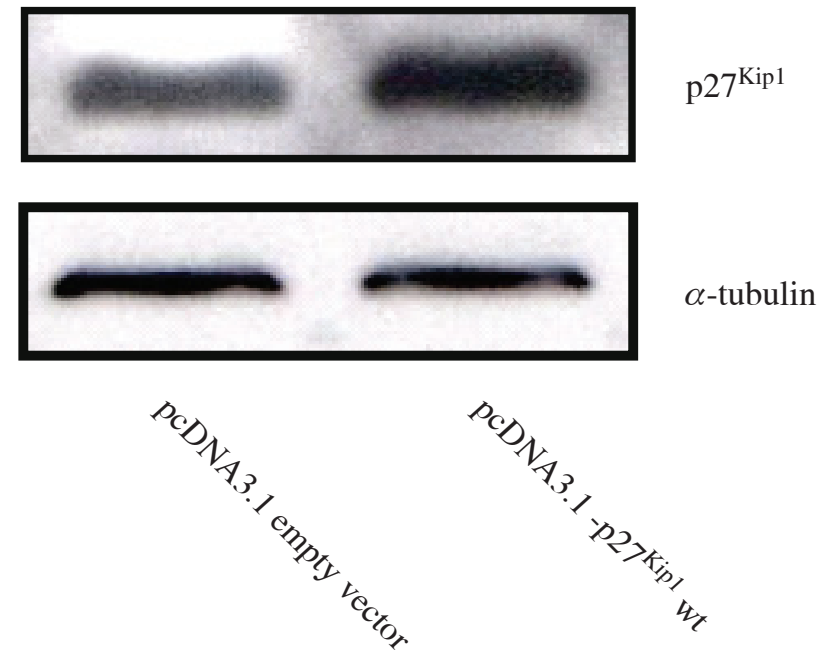

Figure 3. Expression of $\mathrm{p} 27^{\mathrm{Kip} 1}$ and $\alpha$ tubulin protein in the pcDNA3.1 empty vector and pcDNA3.1-p2 ${ }^{\mathrm{Kip} 1} \mathrm{wt}$ transfectant tissues.

was evaluated. As shown in Figure 3, up-regulated of p2 $7^{\text {Kip1 }}$ protein in pcDNA3.1-p27 ${ }^{\text {Kip1 }}$ wt-injected tumors was detected when compared with that in pcDNA3.1 empty vector-injected tumors. The expression of $\alpha$-tubulin as an internal control was approximately the same in all of the tumors.

\section{Detection of apoptosis induces by pcDNA3.1-p27 ${ }^{\mathrm{Kip} 1}$ wt}

To assess the incidence of apoptotic cell death, the internucleosomal DNA fragmentation using the TUNEL method was investigated. The TUNEL-positive cells were significantly increased in tumors electroporated with pcDNA3.1-p27 ${ }^{\text {Kipl }}$ wt when compared with that in samples from xenografts electroporated with pcDNA3.1 empty vector (Figure 4).

\section{DISCUSSION}

Cell membranes electro-gene therapy (electroporation) has been developed for the purpose of achieving highly efficient in vitro gene and/or drug transfer. ${ }^{5}$ Interestingly, the application of electroporation to cultured cells has been well established, but the use of in vivo electroporation has received little attention. ${ }^{12}$ In vivo electro-gene therapy has just recently been proposed for transdermal drug delivery ${ }^{23}$ and for electrochemotherapy with bleomycin of superficial tumors. ${ }^{24}$ Recently, successful in vivo transfer of IL genes into muscle, and transfer of marker and therapeutic suicide genes into normal tissues and tumors has been reported. ${ }^{25}$

In the present study, electro-gene therapy with naked plasmid DNA was evaluated. The wild type $227^{\text {Kip1 }}$ gene

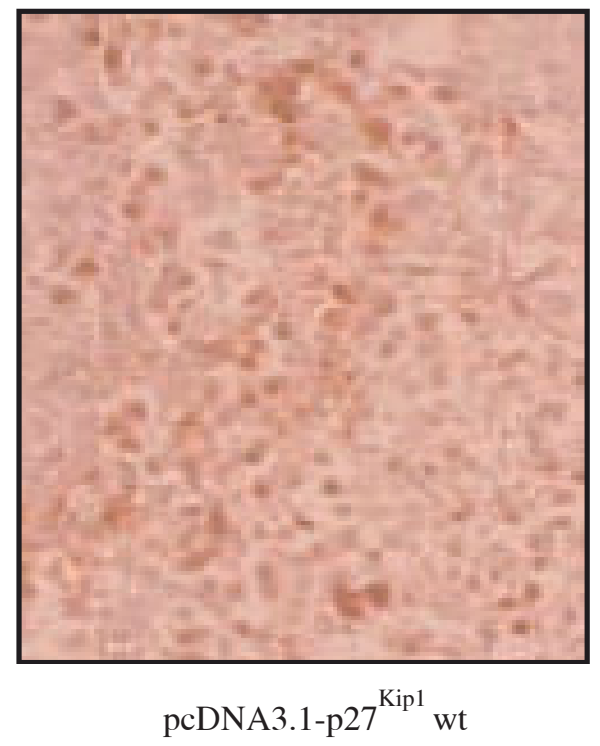

Figure 4. TUNEL, p $27^{\text {Kip1 }}$ staining of SP-C1 xenotransplants. 
was used as a transfection gene and was evaluated its antitumor activity in human oral tongue cancer (SP-C1 cell) xenograft. The results of study demonstrated the efficiency of electro-gene therapy was thought to be about $40-65 \%$ of cells, determined by EGFP expression as shown in figure 1 . Also, it was demonstrated that the transfection of wild type p2 $7^{\text {Kip1 }}$ gene by electro-gene therapy could induce apoptotic cell death (Figure 4), and inhibit the growth of oral cancer xenografts (Figure 2). Also, wild type p2 $7^{\mathrm{Kip} 1}$ gene by electro-gene therapy could induce the expression of $\mathrm{p} 27^{\mathrm{Kip} 1}$ protein (Figure 3), which has the negative regulator function in the cell cycle. Therefore, electro-transfer of plasmid DNA p $27^{\text {Kip } 1}$ wt into SP-C1 xenograft can be successfully achieved using disk-shaped electrodes. Suggesting that clinical application using this electroporation system for oral cancer may be possible in the future.

On the other hands, some disadvantages of this method should be considered. Although transfection by electrogene therapy inhibited the growth of SP-C1 xenografts, the target area was limited to local tumors and the growth of multiple metastatic lesions cannot be target for efficient suppression. For that reason, with a view to obtaining more effective gene therapy using electroporation for oral cancer, I plan to attempt gene transfer with several other genes and to use various anticancer agents in combination with gene transfection by this electro-gene therapy system.

In conclusion, intratumoral injection of pcDNA3.1$\mathrm{p} 27^{\mathrm{Kip} 1} \mathrm{wt}$ gene following in vivo electro-gene therapy has a highly antitumor activity in oral tongue cancer xenografts. It might be possible to transfer pcDNA3.1-p2 ${ }^{\mathrm{Kip} 1}$ wt gene into oral cancer xenograft. In vivo gene transfer method is a simple procedure and can solve some of the critical drawbacks of the present gene transfer techniques, thus providing a new strategy for gene therapy.

\section{ACKNOWLEDGMENTS}

I thank Dr. Koji Harada, DDS., Ph.D and Dr. Takashi Bando, DDS., Ph.D, Second Department of Oral Maxillofacial Surgery and Oncology, School of Dentistry, Tokushima University, Japan, for their valuable advices and providing cancer cell lines.

\section{REFERENCES}

1. Ammar A, Uchida D, Begum NM, Tomizuka Y, Iga H, Yoshida $\mathrm{H}$, et al. The clinicopathological significance of the expression of CXCR4 protein in oral squamous cell carcinoma. Int J Oncol 2004; 25:65-71.

2. Inagi K, Takahashi H, Okamoto M, Nakayama M, Makoshi T, Nagai $H$. Treatment effects in patients with squamous cell carcinoma of the oral cavity. Acta Otolaryngol 2002; Suppl 547:25-29.

3. Parkin DM, Pisani P, Ferlay J. Estimates of the worldwide incidence of 25 major cancers in 1990. Int J Cancer 1999; 80:827-41.
4. Nishi T, Yoshizato K, Yamashiro S, Takeshima H, Sato K, Hamada $\mathrm{K}$, Kitamura I. High efficiency in vivo gene transfer using intra arterial plasmid DA injection following in vivo electroporation. Cancer Res 1996; 56:1050-5.

5. Matthew KE, Dev SB, Toneguzzo F, Keating A. Electroporation for gene therapy. In: Nickoloff JA, editor. Methods in molecular biology. volume 48. Animal Cell Electroporation Protocols, Totowa, NJ: Humana Press, Inc; 1995. p. 273-80.

6. Sukharev SI, Klenchin VA, Serov SM, Chernomordik LV, Chizmadzhev, Yu A. Electroporation and electroporetic DNA transfer into cells: the effect of DNA interaction with electropores. Biophys J 1992; 63:1320-7.

7. Belehradek M, Domenge C, Luboinski B, Orlowski S, Belehradek J Jr, Mir LM. Electrochemotherapy, a new antitumor treatment. First clinical phase I-II trial. Cancer 1993; 72:3694-700.

8. Chu G, Hayakawa H, Berg P. Electroporation for the efficient expression of mammalian cells with DNA. Nucleic Acids Res 1987; 15:1311-26.

9. Suzuki T, Shin BC, Fujikura K, Matsuzaki T, Takata K. Direct gene transfer into rat liver cells by in vivo electroporation. FEBS Lett 1998; 425:436-40.

10. Anderson KP, Lingrel JB. Glucocorticoid and estrogen regulation of a rat T-kininogen gene. Nucleic Acids Res 1989; 17:2835-48.

11. Keating A, Toneguzzo F. Gene transfer by electroporation: a model for gene therapy. Prog Clin Biol Res 1990; 333:491-8.

12. Titomirov AV, Sukharev S, Kristanova E. In vivo electroporation and stable transformation of skin cells of new born mice by plasmid DNA. Biochem Biophys Acta 1991; 1088:131-4.

13. Andreason GL, Evans GA. Optimization of electroporation for transfection of mammalian cells. Anal Biochem 1989; 180:269-75.

14. Jiao S, Williams P, Berg RK, Hodgeman BA, Liu L, Repetto G. Direct gene transfer into non human primate myofibers in vivo. Hum Gene Ther 1992; 3:21-33.

15. Sherr C, Roberts JM. Inhibitors of mammalian G1 cyclin-dependent kinases. Genes Dev 1995; 9:1149-63.

16. Catzavelos C, Bhattacharya N, Ung YC, Wilson JA, Roncari L, Sandhu C. Decreased levels of the cell-cycle inhibitor $\mathrm{p} 27^{\mathrm{Kip} 1}$ protein: prognostic implications in primary breast cancer. Nat Med 1997; 3:227-30.

17. Porter PL, Malone KE, Heagerty PJ, Alexander GM, Gatti LA, Firpo EJ, Daling JR, Robert JM. Expression of cell-cycle regulators $\mathrm{p} 27^{\mathrm{Kip} 1}$ and cyclin $\mathrm{E}$, alone and in combination, correlate with survival in young breast cancer patients. Nat Med 1997; 3:222-5.

18. Harada K, Supriatno, Yoshida H, Sato M. Low p2 $7^{\text {Kip } 1}$ expression is associated with poor prognosis in oral squamous cell carcinoma. Anticancer Res 2002; 22:2985-9.

19. Lloyd RV, Erickson LA, Jin L, Kulig E, Qian X, Cheville JC. p2 $7^{\text {Kip1. }}$ a multifunctional cyclin-dependent kinase inhibitor with prognostic significance in human cancer. M J Pathol 1999; 154:313-23.

20. Nakayama K, Ishida N, Shirane M, Inomata A, Inoue T, Shishido N. Mice lacking p $27^{\mathrm{Kip} 1}$ display increased body size, multiple organ hyperplasia, retinal dysplasia and pituitary tumors. Cell 1996; 85:707-20.

21. Supriatno, Harada K, Kawaguchi S, Yoshida H, Sato M. Effect of $\mathrm{p} 27^{\mathrm{Kip} 1}$ on the ability of invasion and metastasis of an oral cancer cell line. Oncol Rep 2003; 10:527-32.

22. Supriatno, Harada K, Hoque MO, Bando T, Yoshida H, Sato M. Overexpression of $\mathrm{p} 27^{\mathrm{Kip} 1}$ induces growth arrest and apoptosis in an oral cancer cell line. Oral Oncol 2002; 38:730-6.

23. Powel KT, Morgenthaler AW, Weaver JC. Tissue electroporation. Observation of reversible electrical breakdown in viable frog skin. Biophys J 1989; 56:1163-71.

24. Mir LM, Banoun H, Paoletti C. Introduction of definite amounts of non permanent molecules into living cells after electropermeabilization: direct access to the cytosol. Exp Cell Res 1988; 175:15-25.

25. Goto T, Nishi T, Tamura T, Dev SB, Takeshima H, Kochi M. Highly efficient electro-gene therapy of solid tumor by using an expression plasmid for the herpes simplex virus thymidine kinase gene. Proc Natl Acad Sci USA 2000; 97:354-9. 